http://www.ijmp.jor.br v. 11, n. 9, Special Edition (Baltic States), november 2020 ISSN : 2236-269X

DOI: 10.14807/ijmp.v11i9.1410

\title{
COMPUTER MODEL OF RESOURCE DEMAND PLANNING FOR DAIRY FARMS
}

Anatolii Tryhuba Lviv National Agrarian University, Ukraine E-mail: atryguba55@gmail.com

Inna Tryhuba Lviv National Agrarian University, Ukraine E-mail: atryguba55@gmail.com

Iryna Mushenyk State Agrarian and Engineering University in Podilya, Ukraine E-mail: mushenik.77@ukr.net

Oksana Pashchenko National University of Life and Environmental Sciences of Ukraine, Ukraine E-mail: pashchenko@ukr.net

Mykola Likhter National University of Life and Environmental Sciences of Ukraine, Ukraine E-mail:Lih.term@ukr.net IJIM\&P

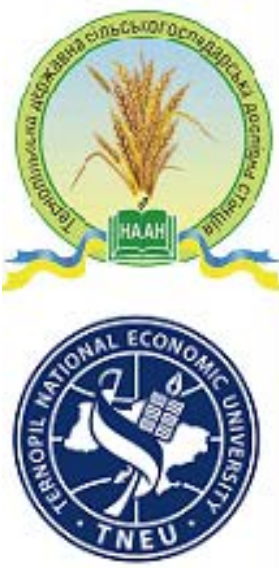

Submission: 8/10/2020 Revision: 8/17/2020 Accept: 8/26/2020

\section{ABSTRACT}

The research presents results of the analysis of scientific and practical conditions of planning of the needs for resources, required for the implementation of the projects of agricultural production. The work substantiates the improvement of the method of forecasting the demand of natural resources, required for fodder production. That method expects the performance of four stages, which are based on production experiments and require computer modeling. The presented method, contrary to the existing ones, considers changeable natural-climatic, subject, organization, and scale constituents of the project environment of the agricultural production projects. Using the developed computer model for forecasting of the natural resource demand for fodder production under conditions of the agricultural servicing cooperative "Pokrova" of Zabolottsi community in Brody district of Lviv region, the work has studied impact of natural-climatic, organization and scale constituents of production conditions on the variation of the natural resource demand. 
DOI: 10.14807/ijmp.v11i9.1410

It is confirmed that the mathematical expectation of the area of the required field for the growing of fodder crops with a proportional change of the milking herd population is made according to polynomial dependencies of the second order. The correlation coefficient of the obtained dependencies is $0.85 \ldots . .0 .99$. It confirms a strong correlation relation between the mathematical expectation of the area of the field, necessary for the growing of fodder crops, and the structure of the milking herd population. The increase of the milking herd population results in the growth of the mathematical expectation and insufficient increase of the meansquare deviation of the area of the field, required for growing of fodder crops.

Keywords: forecasting; resources; agricultural production; computer modelling

\section{INTRODUCTION}

Nowadays, supply of population with food products of appropriate quality is an actual problem. Ukraine possesses great reserves of natural resources for production of agricultural products of good quality both for population of the country and for export. Each year, the territory of Ukraine performs as the area for implementation of agricultural production projects, which require specific instruments for their planning (MACHAL, 2009a; TRYHUBA et al., 2019a; TRYHUBA et al., 2019e; TRYHUBA et al., 2019f).

Nevertheless, the scientific and applied tasks concerning efficient planning of the resource demand for implementation of the projects of agricultural production are not solved. Such projects have their peculiarity as compared to other branches of the economy. Particularly, land, which has its value and productivity on some area, is the principal resource for those projects implementation. Moreover, natural resource demand for some projects of agricultural production depends on the kind of cultivated agricultural crops, their yield capacity, natural-climatic conditions, factors of organization and scale, characterized by stochastic character (ROY et al., 2019; FRAISSE et al., 2006; TRYHUBA et al., 2019b).

Hence, efficiency of planning of agricultural production projects depends on quality of foresting of the resource demand for production of the agricultural products. Such forecast should consider changeable production conditions, which requires labour-intensive calculations. For the reason it is necessary to develop a computer model, which secures studying of the impact of changeable production conditions on the natural resource demand for production of agricultural products. It sufficiently influences quality of the forecast concerning needs for resources, required for production of agricultural products and efficiency of the appropriate projects planning. 
DOI: 10.14807/ijmp.v11i9.1410

\section{LITERATURE REVIEW}

Resource planning tasks related to the development of new and improvement of existing tools in various applied fields have been solved by many scientists (MACHAL, 2009A; TRYHUBA et al., 2019e; RATUSHNY et al., 2019b). The developers of such tools have taken into account the specifics of the subject area. In addition, in order to develop quality tools, one should have a thorough knowledge of the subject area and an accessible database (TRYHUBA et al., 2019e).

The issue of natural resource demand for production of agricultural products is studied in many scientific works (INGELI et al., 2015; CARVAJAL et al., 2019; TRYHUBA et al., 2020). Moreover, a set of researches are devoted to the tasks of the projects planning with consideration of the stochastic project environment (TRYHUBA et al., 2019c; RATUSHNY et al., 2019a; STENCL, 2012). Among them, some works concern the projects of agricultural production, which are characterized by risks (MACHAL, 2009A; TRYHUBA et al., 2019e; RATUSHNY et al., 2019b).

Analysis of the mentioned scientific works concerning their possible use for forecasting of the natural resource demand for implementation of the projects of agricultural production demonstrates their drawbacks. They do not consider peculiarities of changeable weather conditions, which set obstacles for foresting of the variable demand for natural resources, and tendencies of change of their figure depending of the factors of organization and scale of the projects of agricultural production.

To eliminate drawbacks of the above-mentioned methods of determination of the natural resource demand for production of agricultural products, one should develop the appropriate set of tools. The work (MACHAL, 2009B; JERABEK; SPERKOVA, 2015; TRYHUBA et al., 2019d) mentions that adequate managerial decisions in the progress of project implementation is possible of the basis of specific computer models, which consider particularities of their implementation. Considering forecasting of the natural resource demand for production of agricultural products, it is necessary to develop a computer model, which is based on the advanced method, and concerns changeable production conditions (naturalclimatic, organization and scale constituents).

The model will be able to eliminate drawbacks of the existing instruments (approaches, models and methods) (LJASKOVSKA et al., 2018; KONECNY; ZINECKER, 2016). 
DOI: 10.14807/ijmp.v11i9.1410

Particular attention should be paid to the known method (RACHWAN et al., 2016), which expects argumentation of the resource demand for implementation of the projects of milk production by family dairy farms with consideration of changeable natural-climatic conditions and milk yield during the lactation period.

However, that method does not consider the changeable structure of a milking herd population (factors of organization and scale of risk), which is particular for the defined project environment. It is also expected for the average value (mathematical expectation) of duration of the periods of milking herd feeding, which does not meet the actual production conditions. The above-mentioned facts confirm that it is necessary to improve the method of foresting of the natural resource demand for fodder production.

The aim of the work is to develop the instruments for forecasting of the natural resource demand for agricultural production, which are based on computer modelling and consider changeable production conditions.

To reach the set goal, it is necessary to solve the following tasks:

- to improve the method of forecasting of the natural resource demand for fodder production;

- to develop a computer model and study the impact of changeable production conditions on the natural resource demand for fodder production.

\section{MATERIALS AND METHODS}

The quantitative assessment of the natural resource demand for production of agricultural products is proposed to be performed by means of the advanced method. It eliminates drawbacks of the existing methods and expects the following stages: 1) identification of the existing structure of a milking herd, for which fodder production is expected; 2$)$ determination of the annual demand $\left(Q_{k j p}^{i}\right)$ for k-kinds of fodder for $j$-age group of a young herd under their $p$-productivity; 3$)$ calculation of the total annual demand $\left(\bar{Q}_{k}^{i}\right)$ for $k$-kinds of fodder for the set structure of a milking herd; 4) forecast of the area of fields $\left(\bar{S}_{k p}^{i}\right)$, which are intended for growing of fodder crops.

Stage 1. To identify the existing structure of a milking herd, for which the projects of fodder production are intended, the researchers have used the reporting documents of enterprises or local power bodies of their location. It enables determining of the number of head in the milking herd of $j$-age group under their p-productivity. 
DOI: 10.14807/ijmp.v11i9.1410

Stage 2. The annual demand $\left(Q_{k j p}^{i}\right)$ for $k$-kinds of fodder for $j$-age group of the milking herd under their p-productivity is calculated by the formula:

$$
\left(Q_{k j p}^{i}\right)=M\left[Q_{k p}^{i}\right] \cdot t_{b i} \cdot k_{k j p}
$$

where $M\left[Q_{k p}^{i}\right]$ - is the mathematical expectation of the expected daily need for k-kinds of fodder for the $j$-age group of the milking herd under their $p$-productivity in $i$-calendar year, hwt; $t_{b i}$-is duration of $b$-period of the milking herd feeding, during which the $k$-kind of fodder is used, day; $k_{k j p}$ - is the coefficient of a relative need for $k$-kinds of fodder for $j$-age group of the milking herd under their p-productivity.

The mathematical expectation $M\left[Q_{k p}^{i}\right]$ of the expected daily need for $k$-kinds of fodder for a milking herd under their $p$-productivity in i-calendar year is measured by their caloric and nutritional content on the principles of dependencies, argued in the work (TRYHUBA et al., 2019b).

For quantitative assessment of natural-climatic conditions of the region with the use of statistical data for the recognized agro-meteorological stations and methods of mathematical statistics, it is necessary to argue functions of distribution of the theoretical time curves of recovery of the grass stand $f\left(\tau_{v r}\right)$ vegetation in the spring period and time of ground $f\left(\tau_{g f}\right)$ freezing in the period of autumn, and their statistical characteristics (mathematical expectations $M\left(\tau_{v r}\right)$ and $M\left(\tau_{g f}\right)$, mean-square deviations $\sigma\left(\tau_{v r}\right)$ and $\sigma\left(\tau_{g f}\right)$; dispersion $D\left(\tau_{v r}\right)$ and $D\left(\tau_{g f}\right)$, variation coefficients $v\left(\tau_{v r}\right)$ and $v\left(\tau_{g f}\right)$.

It is known (TRYHUBA et al., 2019e), that there are some correlation dependencies between the moment of appearance of a true grass stand $\left(\tau_{g b}\right)$ and the moment of its vegetation $\left(\tau_{v r}\right)$ recovery in the spring period, as well as between the moment of stop of the grass stand ( $\left.\tau_{g e}\right)$ vegetation and the first ground $\left(\tau_{g f}\right)$ freezing in the autumn period of each separate calendar year:

$$
\begin{gathered}
\tau_{g b}=f\left(\tau_{v r}\right), \\
\tau_{g e}=f\left(\tau_{g f}\right) .
\end{gathered}
$$

The dependencies (2) and (3) are determined on the base of the analysis of statistical data of the recognized agro-meteorological stations, considering peculiarities of naturalclimatic conditions of the region, where the corresponding projects are implemented. 
DOI: 10.14807/ijmp.v11i9.1410

The obtained figures of natural-climatic conditions of the region make fundamentals for the forecast of variable duration of the periods of fodder supply. However, duration of the spring ( $\left.t_{t p s}\right)$ and autumn ( $\left.t_{t p a}\right)$ transition periods of cows feeding is forecasted using the dependencies (2) and (3) and with consideration of the figures of time of the grass stand vegetation recovery in the spring period and the first ground freezing in the autumn period of $i$-calendar year, which coincide with the time of completing of housing ( $\left.\tau_{h e}\right)$ and pasture $\left(\tau_{p e}\right)$ seasons of fodder supply family dairy farms (FDF) respectively:

$$
\begin{aligned}
& t_{t p s}^{i}=\tau_{p b}^{i}-\tau_{h e}^{i} \\
& t_{t p a}^{i}=\tau_{h b}^{i}-\tau_{p e}^{i}
\end{aligned}
$$

where $t_{t p s}^{i}, t_{t p a}^{i}$ - is duration of the spring and autumn transition periods of cows feeding respectively in $i$-calendar year, day; $\tau_{p b}^{i}, \tau_{h b}^{i}$ - is the time of start of the pasture and housing seasons of cows feeding respectively in $i$-calendar year, day; $\tau_{p e}^{i}, \tau_{h e}^{i}-$ is the time of finish of the pasture and housing seasons of cows feeding respectively in $i$-calendar year, day. Having figures of the time of start $\left(\tau_{p b}^{i}, \tau_{h b}^{i}\right)$ and finish $\left(\tau_{p e}^{i}, \tau_{h e}^{i}\right)$ of the pasture and housing seasons of cows feeding in $i$-calendar year, one can make forecast of duration of the pasture $\left(t_{p}^{i}\right)$ and housing $\left(t_{h}^{i}\right)$ seasons of cows feeding:

$$
\begin{aligned}
& t_{p}^{i}=\tau_{p e}^{i}-\tau_{p b}^{i}, \\
& t_{h}^{i}=t_{h 1}^{i}+t_{h 2}^{i}=\tau_{h e}^{i}-0+365-\tau_{h b}^{i}=\tau_{h e}^{i}+365-\tau_{h b}^{i},
\end{aligned}
$$

where $t_{p}^{i}, t_{h}^{i}$ - are the periods of duration of pasture and housing seasons of cows feeding respectively in $i$-calendar years, day; $t_{h 1}^{i}, t_{h 2}^{i}$ - are the first and second half-periods of the house feeding in cows in $i$-calendar year, day.

Having performed the appropriate calculations for a set of forecasted calendar years, one gets statistical data for quantitative assessment of the changeable periods of fodder supply, which creates a basis for the forecast of demand for variable cropping area for cultivation of agricultural crops.

Stage 3. The next stage expects determination of the total annual demand $\left(\mathrm{Q}_{-}^{-} \mathrm{k}^{\wedge} \mathrm{i}\right)$ for $\mathrm{k}$ kinds of fodder for the set structure of a milking herd. The mathematical expectation $\mathrm{M}\left(\mathrm{Q}_{-}^{-} \mathrm{k}\right.$ $\wedge$ i) of the predicted daily requirement for k-s types of feed for dairy herd p-th of its productivity in the i-th calendar year is determined by their energy value and nutritional value based on the dependencies that are substantiated in the work (TRYHUBA et al ., 2017). Coefficients (k_kjp) 
DOI: 10.14807/ijmp.v11i9.1410

of the relative demand for k-kinds of fodder for $\mathrm{j}$-age groups of a milking herd under the set $\mathrm{p}$ productivity, constitutes 1.0 - for milking cows; 0.75 - for bred heifers and young cows of the age above 2 years old; 0.5 - for growing stock of 1-2 years old; 0.25 - for calves under 1 year age (TRYHUBA et al., 2017).

The total annual demand $\left(\bar{Q}_{k}^{i}\right)$ for $k$-kinds of fodder for a milking herd, servicing the fodder cooperative (FC), is calculated by the formula:

$$
\bar{Q}_{k}^{i}=\left(\sum_{j=1}^{m} \sum_{p=1}^{n} Q_{k j p}^{i} \cdot n_{j p}\right) \cdot k_{s} \cdot k_{t} \cdot k_{d},
$$

where $n_{j p}$-is livestock of $j$-age group of the milking herd under the set $p$-productivity, animals; $k_{s}, k_{t}, k_{d}$-are coefficients of losses of $k$-kinds of fodder during the periods of its storage, transportation and distribution respectively, as well as because it is not totally eaten by the animals; $m$ - is the number of age groups of the milking herd, units; $n$ - is the number of productivities of the milking herd, units.

Stage 4. Basing on the obtained figures of the total demand $\left(\bar{Q}_{k p}^{i}\right)$ for k-kinds of fodder for a milking herd under their p-productivity in i-calendar year, it is possible to determine the expected area of fields $\left(\bar{S}_{k p}^{i}\right)$, which should be used for its growing:

$$
\bar{S}_{k p}^{i}=\frac{\bar{Q}_{k p}^{i}}{M\left[Y_{s i}\right] \cdot K_{s}},
$$

where $M\left[Y_{s i}\right]$ - is the mathematical expectation of the expected yield capacity of s-kind of a fodder crop on the community territory in i-calendar year, hwt/ha; $K_{S}-$ is the multiplicity of harvesting of the yield of $s$-kind of a fodder crop, units.

The expected yield of $Y_{s i}$ of s-kind of a fodder crop on the community territory is variable, and determination of their quantitative characteristics requires application of statistical data of the community. Basing on application of the methods of mathematical statistics and statistical data concerning yield capacity $Y_{s i}$ of s-kind of a fodder crop in icalendar year, the researchers can obtain a set of them $\left\{Y_{S}\right\}$, which makes a ground for argumentation of density $f\left(Y_{s i}\right)$ of the law of its distribution and determination of its principal characteristics: mathematical expectation

$$
M\left(Y_{S}\right)=\sum_{i=1}^{j} Y_{s i} \cdot P_{i},
$$

where $Y_{s i}$-is the yield of $s$-kind of a fodder crop in the previous $i$-calendar year, hwt/ha; dispersion 
DOI: 10.14807/ijmp.v11i9.1410

$$
D\left(Y_{s}\right)=\sum_{i=1}^{j}\left(Y_{s i}-Y_{s c}\right)^{2} \cdot P_{i}
$$

where $Y_{s c}$ - is the yield of $s$-kind of a fodder crop in $j$-interval of $i$-calendar year, hwt/ha; mean-square deviation

$$
\sigma\left(Y_{s}\right)=\sqrt{D\left(Y_{s}\right)}
$$

coefficient of variation

$$
v\left(Y_{S}\right)=\frac{\sigma\left(Y_{S}\right)}{M\left(Y_{S}\right)}
$$

Making forecast of the demand of total annual needs $\left(\bar{Q}_{k j p}^{i}\right)$ for $k$-kinds of fodder for a milking herd under their $p$-productivity and expected area of fields $\left(\bar{S}_{k p}^{i}\right)$, which should be used for their growing, it is necessary to make a set of calculations for $i$-calendar years with the change of duration $\left(t_{b i}\right)$ of $b$-periods of the milking herd feeding, which are determined at the first stage of that method. The obtained set of figures of the annual demand $\left\{\bar{Q}_{k j p}^{i}\right\}$ for $k$-kinds of fodder of the expected area of field $\left\{\bar{S}_{k p}^{i}\right\}$, intended for its growing, makes a basis for distribution and determination of its principal characteristics by the formulas (10-13), characterizing variation of the natural resource demand.

\section{RESULTS AND DISCUSSION}

A computer model has been developed to make forecast of the natural resource demand for implementation of the projects of fodder supply, as well as to carry a quantitative assessment of the constituents of their project environment. A block diagram and algorithm of the computer model of forecasting of the natural resource demand for implementation of the projects of fodder supply have been developed on the basis of the above-presented method and models of changeable natural-climatic, organization and scale constituents of production conditions. Basing on the mentioned algorithm, the research presents a developed computer model of forecasting of the natural resource demand for implementation of the projects of fodder supply in the language Python 3.6, and its working window is presented by the Fig. 1.

The next stage is to make preliminary modelling to check validity of the model to the actual needs for natural resources for implementation of fodder supply projects. Forecast of the natural resource demand for implementation of the projects for fodder supply has been done for the conditions of the agricultural servicing cooperative "Pokrova". That cooperative is engaged in production of fodder for family milking farms on the territory of Zabolottsi 
DOI: 10.14807/ijmp.v11i9.1410

community of Brody district in Lviv region. Validity of the proposed computer model of forecasting of the natural resource demand for implementation of the projects of fodder supply is checked according to the paired t-test. While checking validity of the model, the experimental and modelled figures of the demand for field area $\left(\bar{S}_{k p}^{i}\right)$, intended for growing of fodder crops, have been compared. It is determined that the deviation of the obtained figures of the required area of fields $\left(\bar{S}_{k p}^{i}\right)$, on the basis of computer modeling and obtained experimental figures of them, does not exceed $2.9 \%$. The fact confirms validity of the developed computer model of forecasting of the natural resource demand for implementation of the projects of fodder supply.

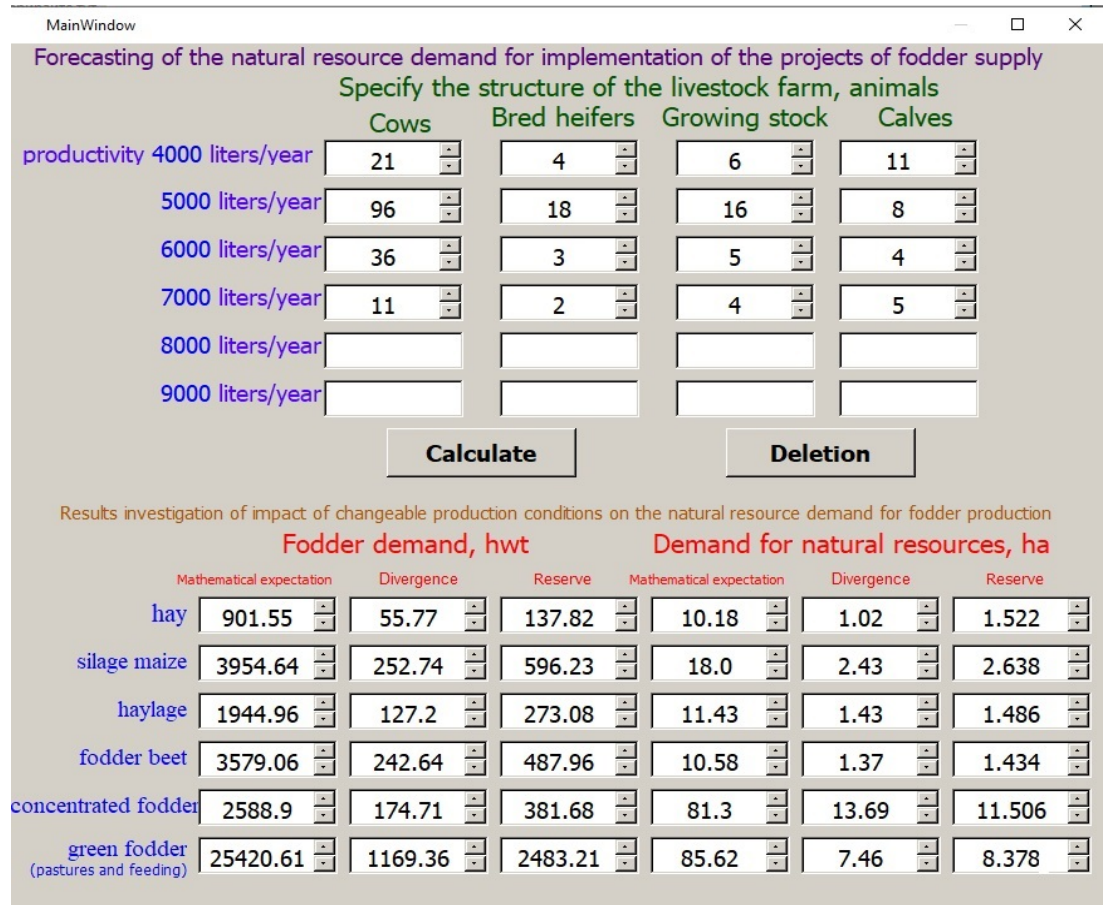

Figure 1: A window of the computer model of forecasting of the natural resource demand for implementation of the projects of fodder supply

The developed computer model has been used to study the impact of changeable production conditions on the demand of natural resources for production of fodder under conditions of the agricultural servicing cooperative "Pokrova". Analysis of the reporting documents of Zabolottsi community, where the agricultural servicing cooperative "Pokrova" is located, has served for setting of the existing structure of the milking herd population (Figs. 2, 3).

Basing on the composed diagram of the structure of the milking herd population of Zabolottsi community in Brody district, which will be serviced by FC, it is argued that the cooperative should plan for the total population of 250 animals. The largest share (55.2 \%) is 
DOI: $10.14807 /$ ijmp.v11i9.1410

taken by the milking herd with the productivity of 5000 liters/year - 138 animals (including cows -96 animals, bred heifers -18 animals, growing stock -16 animals, calves -8 animals).

However, the milking herd also includes the animals with the productivity of 4000 liters/year - 42 animals (18.8 \%), 6000 liters/year (19.2\%), 7000 liters/year - 22 animals ( $8.8 \%$ ). The obtained results concerning the structure of the milking herd population on the territory of Zabolottsi community make a fundamental for forecast of the needs for some kinds of fodder. Nevertheless, there is an adopted housing-pasture way of animals feeding, which is particular for project environment of the cooperative "Pokrova". Feeding diet of the milking herd expects use of concentrated fodder, and consists of hay, haylage, maize silage, concentrated fodder (barley), fodder beet, green fodder (for extra feed and pasture).

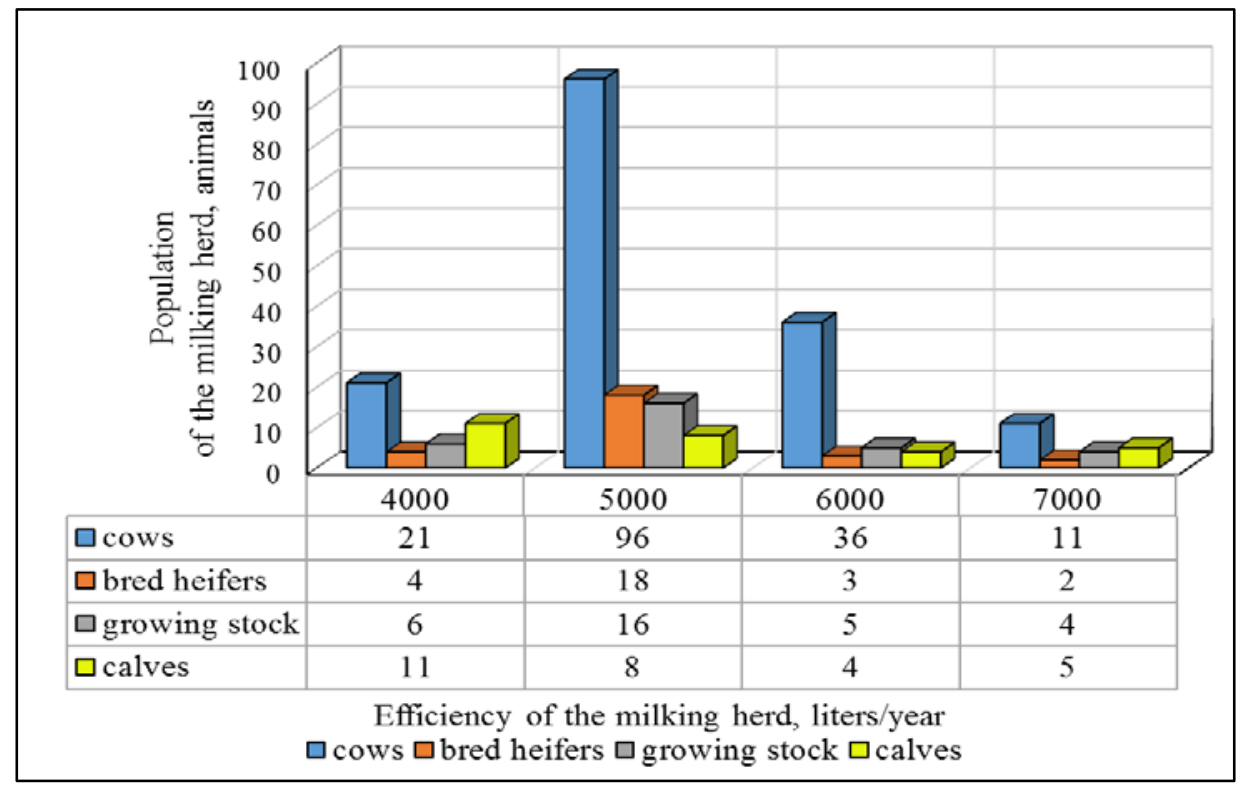

Figure 2: Diagram of the structure of population of the milking herd of Zabolottsi community, which should be supplied with fodder

Using the developed computer model of forecasting of the natural resource demand for implementation of the projects of fodder supply (Fig. 1), the work has studied impact of natural-climatic, organization and scale constituents of production conditions on variation of the demand for natural resources under any change of the milking herd population (Fig. 3). 
DOI: $10.14807 /$ ijmp.v11i9.1410

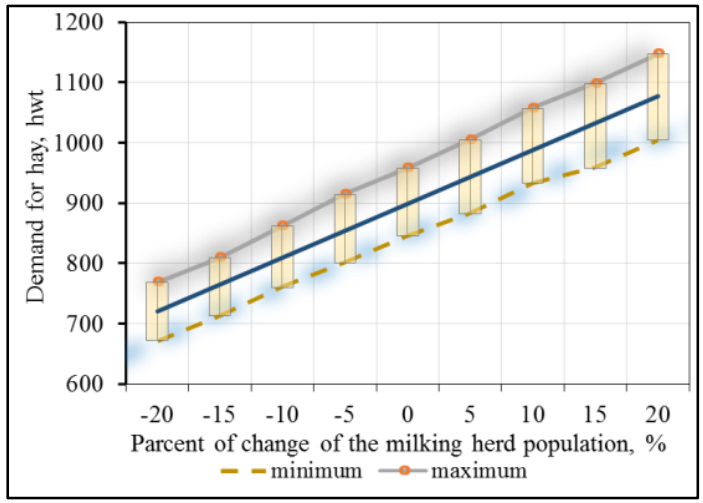

a

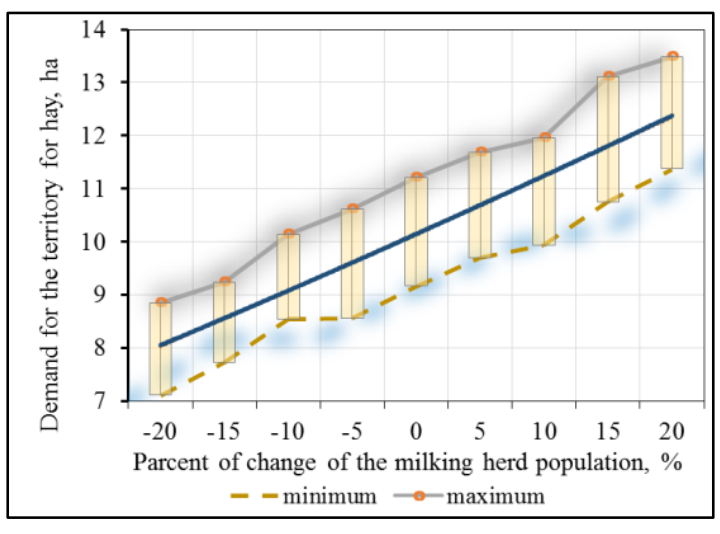

C

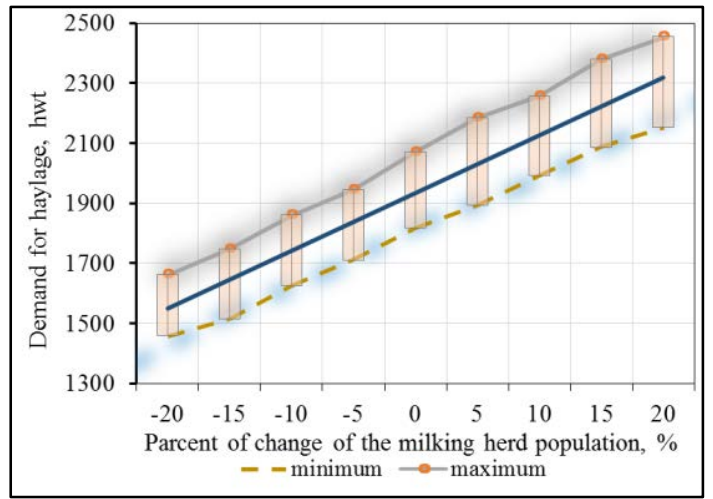

$\mathrm{b}$

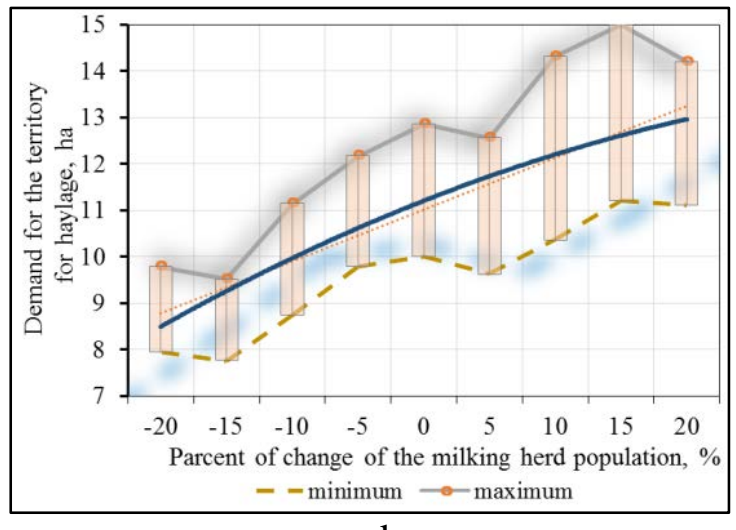

d

Figure 3: Diagram of change of the demand for hay (a) and haylage (b), as well as the area of field for hay (c) and haylage (d) under changeable natural-climatic, organization and scale constituents of production conditions

The composed diagram of change of the demand for some kinds of fodder (Fig. 3) confirms its variable nature. Their figure is influenced both by stochastic natural-climatic conditions, and factors of organization and scale of production conditions on the territory of the mentioned community. It is noted that mathematical expectation $M\left[Q_{i}\right]$ of the need for some kinds of fodder under a proportional change of the milking herd $Z_{n}$ population is changed according to the linear dependencies, described by the equations, which are presented in the Tab. I.

The correlation coefficient of the obtained dependencies (Tab. I) constitutes 0.99, suggesting a strong correlation relation between the mathematical expectation $M\left[Q_{i}\right]$ of the need for some kinds of fodder and structure of the milking herd $Z_{n}$ population. However, one can observe that in case the mathematical expectation $M\left[Q_{i}\right]$ of the demand for some kinds of fodder increases simultaneous with the growth of the milking herd $Z_{n}$ population, the meansquare deviation also increases. It causes growth of risk of the resource demand under the impact of natural-climatic, organization and scale constituents of production conditions of fodder production. 


\section{INDEPENDENT JOURNAL OF MANAGEMENT \& PRODUCTION (IJM\&P)}

http://www.ijmp.jor.br

v. 11, n. 9, Special Edition (Baltic States), november 2020

ISSN: 2236-269X

DOI: 10.14807/ijmp.v11i9.1410

It is marked that the mathematical expectation $M\left[S_{i}\right]$ of the needs for field, intended for growing of fodder crops, with the proportional change of the milking herd $Z_{n}$ population, is changed according to polynomial dependencies of the second order, which are described by the corresponding equations (Tab. I). The correlation coefficient of the obtained dependencies is within $0.85 \ldots 0.99$, confirming a strong correlation relation between the mathematical expectation $M\left[S_{i}\right]$ of the need for field, intended for growing of fodder crops, and structure of the milking herd $Z_{n}$ population. Simultaneously, increase of the milking herd population results in increase of the mathematical expectation $M\left[S_{i}\right]$ and little growth of the mean-square deviation $M\left[G_{i}\right]$ of the need for field, required for fodder crops growing.

Table 1: Equations of dependencies of the mathematical expectation of the need for some kinds of fodder $M\left[Q_{i}\right]$ and area of field $M\left[S_{i}\right]$ for their growing on changes of the milking herd $Z_{n}$ population on the territory of Zabolottsi community

\begin{tabular}{|c|c|c|}
\hline Index & Equation & $\begin{array}{c}\text { Correlation } \\
\text { coefficient }\end{array}$ \\
\hline \multicolumn{3}{|c|}{ Mathematical expectation $M\left[Q_{i}\right]$ of the fodder demand, hwt } \\
\hline Demand for hay & $M\left[Q_{c i}\right]=44.596 \cdot Z_{n}+676.51$ & $r=0.99$ \\
\hline Demand for silage maize & $M\left[Q_{c л}\right]=199.71 \cdot Z_{n}+2948.9$ & $r=0.99$ \\
\hline Demand for haylage & $M\left[Q_{c H}\right]=95.855 \cdot Z_{n}+1454.9$ & $r=0.99$ \\
\hline Demand for fodder beet & $M\left[Q_{\kappa \sigma}\right]=177.59 \cdot Z_{n}+2686.4$ & $r=0.99$ \\
\hline Demand for concentrated fodder & $M\left[Q_{\kappa K}\right]=130.59 \cdot Z_{n}+1955.1$ & $r=0.99$ \\
\hline Demand for green fodder & $M\left[Q_{3 \kappa}\right]=1273.6 \cdot Z_{n}+18944$ & $r=0.99$ \\
\hline \multicolumn{3}{|c|}{ Mathematical expectation $M\left[S_{i}\right]$ of the demand for natural resources, ha } \\
\hline $\begin{array}{l}\text { Area of field under perennial herbs for } \\
\text { hay }\end{array}$ & $M\left[S_{c i}\right]=0.0042 \cdot Z_{n}^{2}+0.4986 \cdot Z_{n}+7.545$ & $r=0.98$ \\
\hline Area of field under maize for silage & $M\left[S_{c r}\right]=-0.0249 \cdot Z_{n}^{2}+1.1126 \cdot Z_{n}+13.204$ & $r=0.95$ \\
\hline $\begin{array}{c}\text { Area of field under perennial herbs for } \\
\text { haylage }\end{array}$ & $M\left[S_{c h}\right]=-0.0298 \cdot Z_{n}^{2}+0.8556 \cdot Z_{n}+7.668$ & $r=0.92$ \\
\hline Area of field under fodder beet & $M\left[S_{i}\right]=0.0185 \cdot Z_{n}^{2}+0.3655 \cdot Z_{n}+8.215$ & $r=0.96$ \\
\hline Area of field under barley & $M\left[S_{i}\right]=-0.4293 \cdot Z_{n}^{2}+8.351 \cdot Z_{n}+51.996$ & $r=0.85$ \\
\hline $\begin{array}{l}\text { Area of field under perennial herbs for } \\
\text { green fodder and pasture }\end{array}$ & $M\left[S_{i}\right]=0.0879 \cdot Z_{n}^{2}+4.0477 \cdot Z_{n}+62.303$ & $r=0.99$ \\
\hline
\end{tabular}

Hence, the carried research determines a figure and impact of natural-climatic, organization and scale constituents of production conditions of fodder production projects on risk of the natural resource demand. The obtained dependencies of mathematical expectation of the demand for some kinds of fodder $M\left[Q_{i}\right]$ and the area of field $M\left[S_{i}\right]$ for their growing, as well as their mean-square deviation $M\left[G_{i}\right]$ on change of the milking herd $Z_{n}$ population on the territory of Zabolottsi community, create fundamentals for qualitative assessment of subject risks in the projects of fodder production and argumentation of responses to the mentioned risks.

\section{CONCLUSIONS}


DOI: 10.14807/ijmp.v11i9.1410

The improved method of forecasting of the natural resource demand for production of fodder expects performance of four stages, which are based on productive experiments and require computer modeling. The proposed method, contrary to the existing ones, considers changeable natural-climatic, subject, organization and scale constituents of the project environment of agricultural production projects. It secures appropriate forecasting of the natural resource demand, as well as assessing of the risk and estimating of reserves of those resources.

Basing on use of the developed computer model of forecasting of the natural resource demand for fodder production under conditions of the agricultural servicing cooperative "Pokrova” of Zabolottsi community in Brody district of Lviv region, the work has studied impact of natural-climatic, organization and scale constituents of production conditions on variation of the demand for natural resources.

It is determined that the mathematical expectation $M\left[S_{i}\right]$ of the need for field, intended for growing of fodder crops, is changed along with a proportional change of the milking herd $Z_{n}$ population according to polynomial dependencies of the second order, which are described by the argued equations (Tab. I). The correlation coefficient of the obtained results are within $0.85 \ldots 0.99$.

It confirms a strong correlation relation between the mathematical expectation $M\left[S_{i}\right]$ of the need for field, intended for growing of fodder crops, and structure of the milking herd $Z_{n}$ population. Moreover, increase of population of the milking herd is followed by increase of mathematical expectation $M\left[S_{i}\right]$ and insufficient growth of the mean-square deviation $M\left[G_{i}\right]$ of the need for field for fodder crops growing.

\section{REFERENCES}

BASHYNSKY, O. (2019) Coordination of dairy workshops projects on the community territory and their project environment. In: 14-th International Scientific and Technical Conference on Computer Sciences and Information Technologies. Lviv Polytechnic National University, 17-20 September. Lviv, p. 51-54.

CARVAJAL, J.; SARACHE, W.; COSTA, Y. (2019) Addressing a robust decision in the sugarcane supply chain: Introduction of a new agricultural investment project in Colombia.

Computers and Electronics in Agriculture, v. 157, p. 77-89.

FRAISSE, C. W.; BREUER, N. E.; ZIERDEN, D.; BELLOW, J. G.; PAZ, J.;

CABRERA, V. E.;... O'BRIEN, J. J. (2006) AgClimate: a climate forecast information system for agricultural risk management in the southeastern USA. Computers and

Electronics in Agriculture, v. 53, n. 1, p. 13-27. 
HULIDA, E.; PASNAK I.; KOVAL, O. (2019) Determination of the Critical Time of Fire in the Building and Ensure Successful Evacuation of People. Periodica Polytechnica Civil Engineering, v. 63, n. 1, p. 308-316.

INGELI, M.; GALAMBOSOVA, J.; PROKEINOVA, R. B.; RATAJ, V. (2015) Application of clustering method to determine production zones of field. Acta Technologica Agriculturae, v. 18, n. 2, p. 42-45.

ISLAM, S.; MANDAL, W. A. (2017) A fuzzy inventory model (EOQ model) with unit production cost,time depended holding cost, without shortages under a space constraint: a fuzzy parametric geometric programming (FPGP) approach. Independent Journal of Management \& Production, v. 8, n. 2, p. 299-318. DOI: 10.14807/ijmp.v8i2.535.

JEŘÁBEK, T.; ŠPERKOVÁ, R. (2015) A predictive likelihood approach to bayesian averaging. Acta Universitatis Agriculturae et Silviculturae Mendelianae Brunensis, v. 63, n. 4, p. 1269-1276.

KONEČNÝ, Z.; ZINECKER, M. (2016) Optimizing risk structure in connection with the corporate life cycle and sector cyclicity. Acta Universitatis Agriculturae et Silviculturae Mendelianae Brunensis, 64, n. 3, p. 949-959.

LJASKOVSKA, S.; MARTYN, Y.; MALETS, I.; PRYDATKO, O. (2018) Information technology of process modeling in the multiparameter systems. In: II International Conference on Data Stream Mining and Processing. Lviv Polytechnic National University, 21-25 August. Lviv, pp. 177-182.

MÁCHAL, P. (2009) Importance of process modelling for the university farm Žabčice of Mendel University of Agriculture and Forestry in Brno. Acta Universitatis Agriculturae et Silviculturae Mendelianae Brunensis, v. 57, n. 4, p. 37-42.

MÁCHAL, P. (2009) Possibilities of application of process modelling when developing a proposal of the business process management system for a university department. Acta Universitatis Agriculturae et Silviculturae Mendelianae Brunensis, v. 57, n. 2, p. 61-68.

PAVLIKHA, N.; RUDYNETS, M.; TRYHUBA, I.; GRABOVETS, V.; SKALYGA, M.; TSYMBALIUK, I.; KHOMIUK, N.; FEDORCHUK-MOROZ, V. (2019) Studying the influence of production conditions on the content of operations in logistic systems of milk collection. Eastern-European Journal of Enterprise Technologies: Control processes, v. 99, n. 3/3, p. 50-63.

RACHWAN, R.; ABOTALEB, I.; ELGAZOULI, M. (2016) The influence of value engineering and sustainability considerations on the project value. Procedia Environmental Sciences, v. 34, p. 431-438.

RATUSHNY, R.; TRYHUBA, A.; BASHYNSKY, O.; PTASHNYK, V. (2019)

Development and usage of a computer model of evaluating the scenarios of projects for the creation of fire fighting systems of rural communities. In: XI-th International Scientific and Practical Conference on Electronics and Information Technologies. Ivan Franko National University of Lviv, 16-18 September. Lviv, pp. 34-39.

RATUSHNYI, R.; KHMEL, P.; MARTYN, E.; PRYDATKO, O. (2019) Substantiating the effectiveness of projects for the construction of dual systems of fire suppression. EasternEuropean Journal of Enterprise Technologies: Control processes, v. 100, n. 4/3, p. 4653.

ROY, P. C.; GUBER, A.; ABOUALI, M.; POUYAN NEJADHASHEMI, A.; DEB, K.; SMUCKER, A. (2019) Crop yield simulation optimization using precision irrigation and 
INDEPENDENT JOURNAL OF MANAGEMENT \& PRODUCTION (IJM\&P)

http://www.ijmp.jor.br

v. 11, n. 9, Special Edition (Baltic States), november 2020

ISSN: 2236-269X

DOI: 10.14807/ijmp.v11i9.1410

subsurface water retention technology. Environmental Modelling \& Software, v. 119, p. 433-444.

RUDYNETS, M.; PAVLIKHA, N.; TRYHUBA, I.; KYTSYUK, I.; KORNELIUK, O.; FEDORCHUK-MOROZ, V.; ... SELEZNOV, D. (2019) Establishing patterns of change in the indicators of using milk processing shops at a community territory. Eastern-European Journal of Enterprise Technologies: Control processes, v. 102, n. 3/6, p. 57-65.

ŠTENCL, M.; POPELKA, O.; ŠTASTNÝ, J. (2012) Forecast of consumer behaviour based on neural networks models comparison. Acta Universitatis Agriculturae et Silviculturae Mendelianae Brunensis, v. 60, n. 2, p. 437-442.

TRYHUBA, A.; BOYARCHUK, V.; TRYHUBA, I.; FTOMA, O. (2019) Forecasting of a lifecycle of the projects of production of biofuel raw materials with consideration of risks.

International Conference on Advanced Trends in Information Theory (ATIT), p. 420425.

TRYHUBA, A., BOYARCHUK, V., TRYHUBA, I., BOYARCHUK, V. \& FTOMA, O. 2019. Evaluation of risk value of investors of projects for the creation of crop protection of family dairy farms. Acta Universitatis Agriculturae et Silviculturae Mendelianae Brunensis, v. 67, n. 5, p. 1357-1367.

TRYHUBA, A.; BOYARCHUK, V.; TRYHUBA, I.; FTOMA, O.; FRANCIK, S.; RUDYNETS, M. (2020) Method and software of planning of the substantial risks in the projects of production of raw material for biofuel. In: International Workshop IT Project Management. Ukrainian Project Management Association “UKRNET” \& Lviv Polytechnic National University, 18-20 February. Slavsko, pp. 116-129.

TRYHUBA, A.; BASHYNSKYI, O.; MEDVEDIEV, Y.; SLOBODIAN, S.;

SKOROBOGATOV, D. (2019) Justification of models of changing project environment for harvesting grain, oilseed and legume crops. Independent Journal of Management \& Production, v 10, n. 7, p. 658-672.

TRYHUBA, A.; HRIDIN, O.; SLAVINA, N.; MUSHENYK, I.; DOBROVOLSKA, E. (2020) Managerial decisions in logistic systems of milk provision on variable production conditions. Independent Journal of Management \& Production, v. 11, n. 8, p. 783-800.

TRYHUBA, A.; TRYHUBA, I.; FTOMA, O.; BOYARCHUK, O. (2019) Method of quantitative evaluation of the risk of benefits for investors of fodder-producing cooperatives. In: 14-th International Scientific and Technical Conference on Computer Sciences and Information Technologies. Lviv Polytechnic National University, 17-20 September. Lviv, p. 55-58. 